\title{
Effects of Oxygen Saturation Fluctuations on Retinopathy in Infants Younger than 30 Weeks' Gestational Age
}

\author{
Chae Woo Jeon, $\mathrm{MD}^{1}$, Ji Su Kim, $\mathrm{MS}^{2}$, Bumhee Park, $\mathrm{PhD}^{2,3}$, and Jang Hoon Lee, $\mathrm{MD}, \mathrm{PhD}^{1}$ \\ ${ }^{1}$ Department of Pediatrics, Ajou University School of Medicine, Suwon, Korea \\ ${ }^{2}$ Office of Biostatistics, Medical Research Collaborating Center, Ajou Research Institute for Innovative Medicine, Ajou University \\ Medical Center, Suwon, Korea \\ ${ }^{3}$ Department of Biomedical Informatics, Ajou University School of Medicine, Suwon, Korea
}

\section{ABSTRACT}

Purpose: To evaluate the risk factors and effects of fluctuations in oxygen saturation on the occurrence and severity of retinopathy of prematurity (ROP).

Methods: From January 1, 2013 to January 31, 2020, 260 patients hospitalized in the neonatal intensive care unit of Ajou University Hospital were retrospectively analyzed. Results: Sixty-six patients (25\%) were diagnosed with ROP; of them 39 required treatment. In the multivariate regression analysis of ROP severity, the odds ratio (OR) of gestational age was 0.32 (95\% confidence interval [CI], 0.22 to $0.47 ; P<0.0001)$. The OR of saturation of peripheral oxygen $\left(\mathrm{SpO}_{2}\right)$ fluctuations at the 4 th week after birth was 1.02 ( $95 \% \mathrm{CI}$, 1.02 to $1.12 ; P=0.041)$.

Conclusion: $\mathrm{SpO}_{2}$ fluctuations in premature infants younger than 30 weeks' gestational age affects ROP severity, especially at the 4 th week of life.

Key Words: Retinopathy of prematurity; Risk factors; Oxygen

\section{서론}

미숙아망막병증(retinopathy of prematurity)은 미숙아에서 망막 혈관의 비정상적인 발달로 일부는 소실되고 일부에서는 비정상적인 신생 혈관들이 형성되어 망막에 변화를 일으키는 질환 으로, 소아 실명의 주요 원인으로 알려져 있다 ${ }^{1-3)} .1950$ 년대 고농도 산소를 사용하였던 미숙아에 서 미숙아망막병증 발생의 위험도가 증가한다는 사실이 밝혀졌고, 그 이후 산소 사용을 제한함 으로써 미숙아망막병증의 발생률이 감소하는 듯 보였으나 최근 의학 기술의 발달로 미숙아의 생존율이 높아지며 그 빈도가 다시 증가하는 추세이달. 미숙아망막병증의 대다수는 특별한 치 료 없이 저절로 호전되지만, 약 $10 \%$ 에서는 냉동응고술이나 레이저광응고술과 같은 수술적 치 료가 필요한 미숙아망막병증으로 발전하며, 그중 일부는 그러한 치료에도 불구하고 심각한 시 력 손상을 가지게 된다.

미숙아망막병증의 위험요인으로 가장 중요한 것으로 출생체중과 재태연령으로 알려져 있고 5, , 그 외에도 신생아 호흡곤란 증후군, 만성 폐질환, 패혈증, 동맥관개존증, 괴사성 장염, 수혈,
Received: 29 July 2020

Revised: 14 October 2020

Accepted: 15 October 2020

Correspondence to: Jang Hoon Lee, $\mathrm{MD}, \mathrm{PhD}$

Department of Pediatrics, Ajou University School of Medicine, 164 World cupro, Yeongtong-gu, Suwon 16499, Korea Tel: +82-31-219-5167

Fax: +82-31-219-5169

E-mail: neopedlee@gmail.com

Copyright(c)

By Korean Society of Neonatology. All right reserved.

This is an Open-Access article distributed under the terms of the Creative Commons At tribution Non-Commercial License (http:// creativecommons.org/licenses/by-nc/4.0), which permits unrestricted non-commercial use, distribution, and reproduction in any medium, provided the original work is pro perly cited. 
뇌실내출혈 등이 있으며-9), 미숙아 출생 이후 상태에 영향을 미치는 여러 요인들이 복합적으로 관여한다고 생각되어진다 ${ }^{10-14)}$.

미숙아망막병증은 2 단계에 걸쳐 일어나는 것으로 알려져 있다. 1 단계에서는 고농도 산소를 공급받음으로써 미숙아의 안구 내에서 혈관형성인자(vascular endothelial growth factor, VEGF)의 발현 억 제가 일어나며, 모체로부터 태반을 통해 전달되던 인슐린유사성장 인자(insulin-like growth factor 1, IGF-1)가 소실됨에 따라 망막의 정상 혈관 성장이 멈추고, 미성숙한 망막 혈관의 폐쇄가 일어나 망 막 주변부가 무혈관 상태에 이른다. 그 후 2단계에서는 미숙아의 안 구가 성장하며 산소 요구량이 많아져 상대적으로 저산소 환경에 놓 이면 VEGF가 증가하게 되고 이와 더불어 혈관 성장에 필요한 IGF-1 이 미숙아 체내에서 만들어지면서 신생 혈관이 증식하게 된다 ${ }^{6,15-18)}$.

지난 20년 동안 여러 관찰 연구 및 코호트 연구들에서 미숙아망막 병증을 예방하기 위한 적절한 산소포화도(saturation of peripheral oxygen)의 목표를 제시하였다. 대부분의 연구에서 낮은 산소포화 도 $\left(70 \%-90 \%{ }^{19)}, 83 \%-89 \%{ }^{20)}\right)$ 를 가진 미숙아에서 심각한 미숙아망막 병증의 발생이 감소된다고 보고하였다. 또한 동물 실험 연구에서 산소포화도의 변동과 미숙아망막병증 발생률 사이에 연관성이 있 다는 사실이 밝혀졌다 ${ }^{21,22)}$. 하지만 이전에는 정확하고 신뢰할만한 방법으로 산소포화도를 측정하는 것이 어려워 산소포화도 변동에 의한 미숙아망막병증의 영향을 평가하는 것이 불가능했으나, 최근 pulse oximetry를 이용하여 비교적 쉬운 방법으로 미숙아의 경피적 산소 측정을 위한 산소포화도의 정확한 절대값을 얻을 수 있게 되었 다. 본 연구에서는 이러한 데이터를 이용하여 미숙아에서 산소포화 도의 변동이 미숙아망막병증의 발생과 중증도에 미치는 영향을 평 가하고자 하였다.

\section{대상 및 방법}

2013년 1월 1일부터 2020년 1월 31일까지 본원에서 출생하여 신생 아집중치료실에 입원한 미숙아 중 재태연령 30주 미만이며 미숙아 망막병증을 확인하기 위해 안저 검사를 받은 환아를 대상으로 하였 다. 첫 안저 검사를 받기 전 전원 가거나 사망한 경우는 제외하였다.

본원에서 미숙아망막병증의 선별검사는 생후 4 주 이후 또는 재 태연령 31주 이후 시행되었으며, 추적 안저 검사는 혈관이 망막의 주변부까지 완전히 형성될 때까지 1-2주 간격으로 시행하였고, 선 별 검사에서 미숙아망막병증이 발견된 경우에는 검사 간격을 중등 도에 따라 안과 전문의의 소견에 의해 개별적으로 조정하여 시행되 었다.

의무기록을 통해 재태연령, 출생체중, 출산 방법, 1 분 및 5 분 아 프가 점수, 신생아 호흡곤란증후군, 기관지폐이형성증, 신생아 지 속성 폐고혈압 등의 신생아 질환을 조사하였고, 미숙아망막병증
의 중증도는 3군으로 나누어, 미숙망막병증이 발생하지 않은 군 (control group), 미숙아망막병증이 발생하였지만 치료 없이 호전된 군(untreated group), 레이저 광응고술 또는 avastin 투여와 같은 치 료가 필요한 군(treated group)으로 구분하였다. 뇌출혈은 뇌초음파 에서 stage 1 이상의 출혈이 있는 경우를 포함하였고, 동맥관개존증 은 3군으로 나누어 동맥관개존증이 없는 군, 동맥관개존증이 발견 되었지만 약물적 치료나 수술적 치료 없이 저절로 호전된 군(spontaneous), 약물적 치료나 수술적 치료가 개입된 군(symptomatic)으 로 나누었다. 기관지폐이형성증은 2000년 미국 국립보건원에서 제 시한 기준(National Institutes of Health consensus definition)을 사 용하였으며, 출생 후 최소 28 일간 산소 치료를 받은 환아에서 교정 연령 36주 또는 퇴원 시점 중 빠른 시기에 산소 의존도가 없을 경우 를 경증(mild), fraction of inspired oxygen $\left(\mathrm{FiO}_{2}\right) 0.3$ 미만의 산소가 필요한 경우에는 중등도(moderate), $\mathrm{FiO}_{2} 0.3$ 이상의 산소나 양압 환기가 필요한 경우에는 중증(severe)의 기관지폐이형성증으로 구 분하였다. 신생아 지속성 폐동맥고혈압은 심장초음파로 확인된 폐 고혈압 또는 기계환기를 유지한 상태에서 고농도산소분압과 동시 에 흡인 일산화질소(inhaled nitric oxide)를 사용한 경우로 정의하 였다. 괴사성 장염은 $2 \mathrm{~A}$ 이상의 단계로 한정하였으며, 초기 소생술 유무는 출생 당시 흥부 압박(cardiac massage)이 필요한 경우, 패혈 증은 혈액에서 균주가 확인된 경우로 정의하였다. 본원에서 산소포 화도의 목표 범위는 생후 첫 1주간은 90\%-95\%, 그 후는 93\%-98\% 였으며, 본 연구에 사용된 산소포화도는 전산화로 자동 기록된 시간 당 산소포화도를 기준으로 하루 동안의 산소포화도 변동을 산출했 으며, 산소포화도의 변동은 출생 후 첫 4 주의 기간 동안 산소포화도 의 최대값과 최소값 절대값 차이 및 산소포화도의 표준편차로 정의 하였다.

본 연구의 데이터는 후향적으로 수집한 대상 환아의 임상자료로 연속형 변수는 정규성과 등분산성을 만족하지 않아 중앙값(사분위 수)를 제시하였으며, 범주형 변수는 발생에 따라 수(percent)를 제 시하였다. 각 변수별로 세 집단 간 차이를 비교하기 위해 KruskalWallis $H$ test와 chi-square test 또는 Fisher's exact test를 각각 연속 형 및 범주형 변수에 사용하였으며, 집단 간 차이를 보기 위하여 post hoc test를 시행하였다. 미숙아망막병증에 영향을 미치는 위험요 인을 분석하기 위해 cumulative ordinal logistic regression analysis 를 시행하였고, 잠재적 혼란 요인을 조정하면서 주요 결과와 관련 된 요인을 식별하기 위해 모형의 적합성(fitting)의 측도인 Akaike information criterion criteria를 기준으로 단계적 회귀분석(stepwise regression)을 통해 변수를 선택하여 multivariable cumulative ordinal logistic regression analysis를 시행하였다.

R software version 3.6.3 (R Foundation for Statistical Computing, Vienna, Austria)을 사용하여 통계를 시행하였으며, 모든 분석에서 $P$-value 0.05 미만인 경우를 통계적으로 유의한 것으로 간주하였 
다(post hoc test의 경우 Bonferroni correction 방법에 따라 P-value $0.0167[=0.05 / 3]$ 미만을 기준으로 통계적으로 유의한 것으로 간주 하였다).

\section{결과}

전체 330 명 환아 중 연구 기준에 부합하는 환아는 총 260 명이었 다. 260명 대상 환아 중 미숙아망막병증으로 진단받은 환아는 66명 (25\%)이었으며, 미숙아망막병증으로 진단받은 환아 중 27 명(10\%)
이 저절로 호전된 반면, 39명(15\%)이 수술적 치료를 필요로 하였으 며(Table 1), Zone 1에서의 발생은 3명(1\%)이었다. 각 군에서 성별 과 출산 방법은 의미 있는 차이를 보이지 않았다.

\section{1. 위험요인}

본 연구에서 재태연령과 출생체중, 1 분 및 5 분 아프가 점수가 미 숙아망막병증 중증도에 따른 세 군 사이에 통계적인 차이가 있었고 (Table 1), 치료가 개입된 동맥관개존증, 산소 사용일수, 인공호흡 기 사용일수, 중등도 이상의 기관지폐이형성증, 신생아 지속성 폐 동맥 고혈압, 수혈 횟수, 괴사성 장염, 신생아집중치료실 재원 기간

Table 1. Patients' Demographic Characteristics

\begin{tabular}{|c|c|c|c|c|}
\hline \multirow{2}{*}{ Characteristic } & \multicolumn{4}{|c|}{ ROP severity } \\
\hline & Control $(n=194)$ & Untreated ROP $(n=27)$ & Treated ROP $(n=39)$ & $P$-value \\
\hline Male sex & $112(57.7)$ & $14(51.9)$ & $22(56.4)$ & 0.8440 \\
\hline GA (wk) & $28(24-29)$ & $26(24-28)$ & $25(23-29)$ & $<0.0001$ \\
\hline Birth weight (g) & $1,175(540-1,770)$ & $970(670-1,260)$ & $800(420-1,100)$ & $<0.0001$ \\
\hline C-sec & $140(72.2)$ & $18(66.7)$ & $24(61.5)$ & 0.3857 \\
\hline Apgar at $1 \mathrm{~min}$ & $4(0-8)$ & $4(1-7)$ & $3(0-6)$ & 0.0042 \\
\hline Apgar at $5 \mathrm{~min}$ & $6(0-9)$ & $6(2-8)$ & $4(1-8)$ & 0.0007 \\
\hline
\end{tabular}

Values are expressed as number (\%) or median (range).

Abbreviations: ROP, retinopathy of prematurity; GA, gestational age; C-sec, cesarean section.

Table 2. Patients' Clinical Characteristics

\begin{tabular}{|c|c|c|c|c|c|c|c|}
\hline \multirow[b]{2}{*}{ Characteristic } & \multicolumn{4}{|c|}{ ROP severity } & \multicolumn{3}{|c|}{ Post hoc } \\
\hline & $\begin{array}{l}\text { Control } \\
(n=194)\end{array}$ & $\begin{array}{l}\text { Untreated ROP } \\
\quad(n=27)\end{array}$ & $\begin{array}{l}\text { Treated ROP } \\
\quad(n=39)\end{array}$ & $P$-value & $\begin{array}{l}\text { Control vs. } \\
\text { Untreated }\end{array}$ & $\begin{array}{l}\text { Control vs. } \\
\text { Treated }\end{array}$ & $\begin{array}{c}\text { Untreated vs. } \\
\text { Treated }\end{array}$ \\
\hline PDA & & & & $<0.0001$ & 0.2003 & $<0.0001$ & 0.0054 \\
\hline None & $70(36.1)$ & $6(22.2)$ & $1(2.6)$ & & & & \\
\hline Spontaneous & $68(35.1)$ & $9(33.3)$ & 7 (17.9) & & & & \\
\hline Symptomatic & $56(28.9)$ & $12(44.4)$ & $31(79.5)$ & & & & \\
\hline IVH & $0(0-4)$ & $1(0-3)$ & $1(0-4)$ & $<0.0001$ & 0.5463 & $<0.0001$ & 0.0078 \\
\hline $\mathrm{O}_{2}$ apply duration (d) & $37(2-274)$ & $56(4-125)$ & $91(16-316)$ & $<0.0001$ & 0.0103 & $<0.0001$ & 0.0016 \\
\hline Ventilator duration (d) & $2(0-274)$ & $10(0-115)$ & $41(0-316)$ & $<0.0001$ & 0.0007 & $<0.0001$ & 0.0065 \\
\hline Mild BPD & $130(7.6)$ & $25(92.6)$ & $37(84.9)$ & 0.0006 & 0.1830 & 0.0009 & 1.0000 \\
\hline Moderate to severe BPD & $42(21.6)$ & $12(44.4)$ & $33(84.6)$ & $<0.0001$ & 0.0156 & $<0.0001$ & 0.0832 \\
\hline RDS & $136(70.1)$ & $24(88.9)$ & $33(84.6)$ & 0.0308 & 0.0410 & 0.0770 & 0.7270 \\
\hline PPHN & $24(12.4)$ & $6(22.2)$ & $15(38.5)$ & 0.0003 & 0.2712 & 0.0002 & 0.2611 \\
\hline RBC transfusion & $2(0-48)$ & $5(0-38)$ & $8(0-132)$ & $<0.0001$ & 0.0002 & $<0.0001$ & 0.0296 \\
\hline Initial resuscitation & $16(8.2)$ & $2(7.4)$ & $12(30.8)$ & 0.0009 & 1.0000 & 0.0004 & 0.0314 \\
\hline Sepsis & $20(10.3)$ & $8(29.6)$ & $13(33.3)$ & 0.0002 & 0.0101 & 0.0006 & 0.7942 \\
\hline NEC & $8(4.1)$ & $3(11.1)$ & $5(12.8)$ & 0.0417 & 0.1375 & 0.0469 & 1.0000 \\
\hline $\operatorname{HOD}(d)$ & $57(30-173)$ & $66(46-154)$ & $109(51-231)$ & $<0.0001$ & 0.0117 & $<0.0001$ & 0.0007 \\
\hline
\end{tabular}

Values are expressed as number (\%) or median (range).

Abbreviations: ROP, retinopathy of prematurity; PDA, patent ductus arteriosus; IVH, intraventricular hemorrhage; BPD, bronchopulmonary dysplasia; RDS, respiratory distress syndrome; PPHN, persistent pulmonary hypertension of the newborn; RBC, red blood cell; NEC, necrotizing enterocolitis; HOD, hospital day. 
이 미숙아망막병증 중증도의 각 군 사이에 유의한 차이를 보였다 (Table 2).

단변량분석과 사후검정에 따르면 중등도 이상의 기관지폐이형성 증, 수혈 횟수, 패혈증은 대조군과 미숙아망막병증 발생군(미치료 군과 치료군) 사이에 유의한 차이를 보였고, 산소사용일수, 기계환 기일수, 신생아집중치료실 재원 기간은 모든 집단 사이에 유의한 차 이가 있었다(Table 2).

\section{2. 산소포화도 변동과 미숙아망막병증 중증도}

미숙아의 신생아집중치료실 재원 기간 중 생후 4 주간의 평균 산 소포화도 변동(절대값 차이, 표준편차)은 미숙아망막병증의 중증도 에 따른 차이를 보였다 $(P=0.0003, P<0.0001)$ (Table 3). 또한, 출생 후 1 주 차부터 4 주 차까지 모든 주 수에서의 산소포화도 변동(절대 값 차이, 표준편차) 역시 각 군 사이에 유의한 차이가 있었다(Table 3).

\section{3. 미숙아망막병증 위험요인의 단변량분석}

재태연령의 비교 위험도는 0.31 (95\% confidence interval [CI], $0.24-0.40 ; P<0.0001)$ 로 재태연령이 1주 증가할수록 미숙아망막병 증의 발생은 0.31 배 감소하였으며, 출생체중의 비교 위험도는 0.99 (95\% CI, 0.99-0.99; $P<0.0001)$ 로 출생체중이 $200 \mathrm{~g}$ 증가할수록 미 숙아망막병증의 발생률이 0.99 배 감소하였다. 치료가 개입된 동맥 관개존증의 비교위험도는 8.57 (95\% CI, 3.59-20.45; $P<0.0001)$, 중등도 이상의 기관지폐이형성증의 비교위험도는 $5.16(95 \% \mathrm{CI}$, $2.87-9.28 ; P<0.0001)$, 괴사성 장염의 비교위험도는 3.06 (95\% CI, 1.16-8.06; $P=0.024)$ 으로 확인되었다(Table 4). 또한 출생 후 첫 4주 간의 산소포화도 변동(절대값 차이, 표준 편차)의 비교 위험도는 각
각 1.07, 1.34 (95\% CI, 1.03-1.12; 95\% CI, 1.12-1.59) 였고, 출생 후 3 주 차를 제외하고 4주 차까지 산소포화도 변동의 비교위험도가 1 이상으로 미숙아망막병증과의 양의 상관관계가 통계적으로 유의하 였다(Table 4).

\section{4. 미숙아망막병증 위험요인의 다변량분석}

재태연령과 출생체중의 비교위험도는 각각 $0.32,1.00(95 \% \mathrm{CI}$, 0.22-0.47; 95\% CI, 0.99-1.00; $P<0.05)$ 이었고, 중등도 이상의 기관 지폐이형성증은 비교위험도가 2.38 (95\% CI, 0.99-5.71; $P=0.0519)$, 출생 후 4 주 차의 산소포화도의 변동(절대값 차이)의 비교위험도는 1.02 (95\% CI, 1.02-1.12; $P=0.041)$ 로 확인되었다(Table 5).

\section{5. 출생 주 수에 따른 산소포화도 변동과 미숙아망막병증 중증 도의 상관관계}

출생 후 1 주 차에서 4 주 차까지의 산소포화도 변동(절대값 차이 와 표준편차)의 상관계수는 0.1 이상으로 미숙아망막병증의 중증 도와 약한 양의 상관관계를 가지고 있었고 $(P<0.05)$, 특히 출생 후 1 주 차의 산소포화도 변동(절대값 차이와 표준편차)의 상관계수가 $0.27,0.30(P<0.0001)$ 으로 다른 주에 비해 높은 상관관계에 있었다 (Table 6).

\section{고찰}

본 논문은 미숙아에서 산소포화도의 변동이 미숙아망막병증의 발생과 중증도에 미치는 영향을 평가하고자 하였다. 연구 결과, 30 주 미만의 미숙아에서 신생아집중치료실 재원 기간 중 생후 4주간

Table 3. $\mathrm{SpO}_{2}$ Fluctuations and Retinopathy of Prematurity Severity

\begin{tabular}{|c|c|c|c|c|c|c|c|}
\hline \multirow[b]{2}{*}{$\mathrm{SpO}_{2}$ fluctuation } & \multicolumn{4}{|c|}{ ROP severity } & \multicolumn{3}{|c|}{ Posthoc } \\
\hline & $\begin{array}{c}\text { Control A } \\
(n=194)\end{array}$ & $\begin{array}{l}\text { Untreated ROP } \\
\quad(n=27)\end{array}$ & $\begin{array}{c}\text { Treated ROP } \\
(n=39)\end{array}$ & $P$-value & $\begin{array}{l}\text { Control vs. } \\
\text { Untreated }\end{array}$ & $\begin{array}{l}\text { Control vs. } \\
\text { Treated }\end{array}$ & $\begin{array}{c}\text { Untreated vs. } \\
\text { Treated }\end{array}$ \\
\hline 1-week & $14(0.9-44.9)$ & $18.4(3.9-47.3)$ & $19.9(8.1-49.1)$ & 0.0001 & 0.1858 & 0.0001 & 0.1858 \\
\hline 2-week & $15(1.1-58.4)$ & $17.7(3.7-44.7)$ & $17.3(3.3-50.1)$ & 0.0371 & 0.1462 & 0.1462 & 0.7806 \\
\hline Standard deviation & $3.8(1.5-10.1)$ & $4.7(3.2-8.4)$ & $4.6(2-9.2)$ & $<0.0001$ & 0.0034 & 0.0007 & 0.9967 \\
\hline 1-week & $3.2(0.2-13.1)$ & $4.5(1.1-10.2)$ & $4.6(2.4-13.7)$ & $<0.0001$ & 0.0673 & $<0.0001$ & 0.1334 \\
\hline 2-week & $3.6(0.3-14.1)$ & $4.2(0.8-11.9)$ & $4.4(0.8-11.7)$ & 0.0129 & 0.0740 & 0.0740 & 0.8106 \\
\hline 3-week & $4(0.6-14.4)$ & $4.9(2.8-16.1)$ & $4.7(1.8-14.4)$ & 0.0371 & 0.0717 & 0.2526 & 0.4344 \\
\hline
\end{tabular}

Values are expressed as median (range).

Abbreviations: $\mathrm{SpO}_{2}$, saturation of peripheral oxygen; $\mathrm{ROP}$, retinopathy of prematurity. 
Table 4. Risk Factors of Retinopathy of Prematurity Severity (Univariate Cumulative Ordinal Logistic Regression Analysis)

\begin{tabular}{|c|c|c|c|}
\hline Variable & OR & $95 \% \mathrm{CI}$ & $P$-value \\
\hline GA & 0.31 & $0.24-0.40$ & $<0.0001$ \\
\hline Birth weight & 0.99 & $0.99-0.99$ & $<0.0001$ \\
\hline \multicolumn{4}{|l|}{ PDA } \\
\hline Spontaneous & 2.38 & $0.93-6.14$ & 0.0714 \\
\hline Symptomatic & 8.57 & $3.59-20.45$ & $<0.0001$ \\
\hline IVH & 1.84 & $1.42-2.39$ & $<0.0001$ \\
\hline $\mathrm{O}_{2}$ apply duration & 1.03 & $1.02-1.04$ & $<0.0001$ \\
\hline Ventilator duration & 1.03 & $1.02-1.05$ & $<0.0001$ \\
\hline Mild BPD & 6.46 & $2.25-18.58$ & 0.0005 \\
\hline Moderate to severe BPD & 5.16 & $2.87-9.28$ & $<0.0001$ \\
\hline RDS & 2.63 & $1.22-5.65$ & 0.0132 \\
\hline $\mathrm{RBC}$ transfusion & 1.14 & $1.08-1.19$ & $<0.0001$ \\
\hline Sepsis & 3.85 & $1.98-7.47$ & 0.0001 \\
\hline NEC & 3.06 & $1.16-8.06$ & 0.0240 \\
\hline HOD & 1.04 & $1.03-1.05$ & $<0.0001$ \\
\hline $\mathrm{SpO}_{2}$ fluctuation (max-min) & 1.07 & $1.03-1.12$ & 0.0021 \\
\hline 1-week & 1.05 & $1.02-1.09$ & 0.0005 \\
\hline 2-week & 1.03 & $1.01-1.06$ & 0.0182 \\
\hline 3-week & 1.02 & $1.00-1.05$ & 0.0930 \\
\hline 4-week & 1.03 & $1.01-1.06$ & 0.0164 \\
\hline $\mathrm{SpO}_{2}$ fluctuation (SD) & 1.34 & $1.12-1.59$ & 0.0011 \\
\hline 1-week & 1.26 & $1.12-1.42$ & 0.0001 \\
\hline 2 week & 1.14 & $1.02-1.27$ & 0.0175 \\
\hline 3-week & 1.07 & $0.98-1.18$ & 0.1313 \\
\hline 4-week & 1.14 & $1.03-1.26$ & 0.0123 \\
\hline
\end{tabular}

Abbreviations: OR, odds ratio; CI, confidence interval; GA, gestational age; PDA, patent ductus arteriosus; IVH, intraventricular hemorrhage; $\mathrm{BPD}$, bronchopulmonary dysplasia; RDS, respiratory distress syndrome; RBC, red blood cell; NEC, necrotizing enterocolitis; HOD, hospital day; $\mathrm{SpO}_{2}$, saturation of peripheral oxygen; $\mathrm{SD}$, standard deviation.

Table 5. Risk Factors of Retinopathy of Prematurity Severity (Multivariate Cumulative Ordinal Logistic Regression Analysis)

\begin{tabular}{lccc}
\hline Variable & OR & $95 \%$ CI & $P$-value \\
\hline GA & 0.32 & $0.22-0.47$ & $<0.0001$ \\
Birth weight & 1.00 & $0.99-1.00$ & 0.0258 \\
Apgar at 1 min & 1.19 & $0.94-1.52$ & 0.1525 \\
Moderate to severe BPD & 2.38 & $0.99-5.71$ & 0.0519 \\
SpO $_{2}$ fluctuation average & 1.33 & $0.97-1.82$ & 0.0774 \\
2-Week $\mathrm{SpO}_{2}$ fluctuation (max-min) & 0.97 & $0.93-1.01$ & 0.0961 \\
4-Week $\mathrm{SpO}_{2}$ fluctuation (max-min) & 1.02 & $1.02-1.12$ & 0.041 \\
\hline
\end{tabular}

Abbreviations: OR, odds ratio; $\mathrm{CI}$, confidence interval; GA, gestational age; $\mathrm{BPD}$, bronchopulmonary dysplasia; $\mathrm{SpO}_{2}$, saturation of peripheral oxygen.
Table 6. Correlation between $\mathrm{SpO}_{2}$ by Weeks after Birth and Retinopathy of Prematurity

\begin{tabular}{lcr}
\hline Variable & Correlation coefficient & $P$-value \\
\hline $\mathrm{SpO}_{2}$ fluctuation (max-min) & & \\
1-week & 0.27 & $<0.0001$ \\
2-week & 0.16 & 0.0122 \\
3-week & 0.15 & 0.0134 \\
4-week & 0.16 & 0.0104 \\
$\mathrm{SpO}_{2}$ fluctuation (SD) & & \\
1-week & 0.30 & $<0.0001$ \\
2-week & 0.18 & 0.0038 \\
3-week & 0.14 & 0.0206 \\
4-week & 0.16 & 0.0084 \\
\hline
\end{tabular}

Abbreviations: $\mathrm{SpO}_{2}$, saturation of peripheral oxygen; $\mathrm{SD}$, standard deviation.

의 평균 산소포화도 변동(절대값 차이, 표준편차)은 미숙아망막병 증의 중증도에 따른 차이를 보였고, 출생 후 4주차의 산소포화도의 변동이 커질수록 미숙아망막병증의 중증도가 증가하였다. 또한, 미 숙아망막병증의 발생과 중증도에 영향을 미치는 미숙아의 여러 요 인 중 재태연령이 유의미한 인자로 확인되었다. 단변량분석과 상관 분석에서 다른 주수에 비해 생후 1 주 차 산소포화도 변동의 비교위 험도 및 상관계수가 높아 생후 1주 차 산소포화도 변동의 영향이 더 큰 것으로 보였지만, 단계적 회귀분석을 통해 선택된 변수로 보정된 다변량분석에서는 생후 4 주 차의 산소포화도 변동이 중증도에 대한 유의미한 인자로 확인되었다. 이는 생후 출생 초기일수록 미숙아의 불안정한 전신 상태가 미숙아망막병증에 복합적으로 영향을 미치 며, 후기로 갈수록 이러한 상태가 해결되면서 산소포화도 변동의 영 향이 더 커지기 때문으로 생각된다.

쥐를 대상으로 한 동물 실험 연구에서 partial pressure of oxygen $\left(\mathrm{PaO}_{2}\right)$ 변동이 비정상적인 망막 혈관 성장 발달에 중요한 역할을 한 다는 사실이 입증되었고, 적은 양의 산소가 지속적으로 노출되는 경 우보다 산소 변동이 있었던 경우 망막 혈관의 손상이 더 심했으며, 변동의 정도와 망막 혈관 병리의 정도가 양의 상관관계가 있었다 ${ }^{23)}$. 이는 미숙한 망막 혈관이 저산소 또는 과산소, 대사성 산증과 같은 환경적 요인에 취약하기 때문인 것으로 생각되며, 산소 변동이 클수 록 저산소 또는 과산소 환경에 자주 노출되므로 망막 혈관의 성장에 영향을 미치는 것으로 생각된다.

혈중의 산소 변동이 미숙아망막병증에 영향을 미친다는 동물 실 험 연구 이후 실제로 미숙아의 산소 변동과 미숙아망막병증 사이의 관계를 연구하는 많은 시도들이 있었다. Saito 등 ${ }^{24)}$ 에 따르면 18명의 미숙아를 대상으로 한 연구에서 3 단계 이상의 미숙아망막병증을 가 진 환아의 $\mathrm{PaO}_{2}$ 변동이 더 컸고, Cunningham 등 ${ }^{25)}$ 이 진행한 후향적 연구에서는 3 단계 이상의 미숙아망막병증 환아 38 명과 미숙아망막 병증이 없거나 1-2단계의 환아들을 비교한 결과 생후 2 주 동안의 경 
피적 산소 농도의 변동이 심각한 미숙아망막병증의 진행에 유의미 한 예측 인자로 작용하였다. Das 등 ${ }^{26)}$ 은 56 명의 극소저체중아의 생 후 첫 4주간 산소포화도를 평가했고, 대조군과 비교하여 중등-중증 도의 미숙아망막병증을 가진 환아들의 산소포화도 변동이 유의미 하게 증가함을 밝혔다. Imanishi 등 ${ }^{22)}$ 의 연구에서는 32 주 미만의 미 숙아에서 산소포화도 변동이 치료를 필요로 하는 심각한 미숙아망 막병증의 발생과 연관이 있었다.

본 연구는 다른 연구에서 입증되었던 산소포화도의 변동과 미숙 아망막병증의 사이의 연관성뿐만 아니라 산소포화도 변동이 미숙 아망막병증에 가장 큰 영향을 주는 시점에 대해서 알아보고자 하였 다. 그 결과 우리나라 다수의 미숙아를 대상으로 정확한 산소포화도 데이터로 진행된 본 논문에서 임상적으로 실제적인 치료를 필요로 하는 미숙아망막병증의 발생과 생후 첫 4주 차의 산소포화도 변동 이 유의미한 연관이 있었다.

하지만 본 연구에는 여러 제한점이 있다. 첫 번째로 이 연구는 단 일 기관에서 시행한 후향적 연구이기 때문에 계획된 프로토콜을 가 지고 진행된 연구가 아니며, 표본 크기에 비해 다변량분석의 변수가 많은 것이 단일기관 소규모 연구의 한계로 생각된다. 두 번째로 산 소포화도 데이터가 다른 연구에서는 분당 산소포화도로 진행되었 지만 본 연구에서는 시간당 산소포화도로, 정밀한 간격으로 측정된 산소포화도가 더 정확한 결과를 도출할 것으로 보인다.

결론적으로, 미숙아망막병증에 영향을 미치는 요인 중 이전 연구 에서 여러 차례 확인되었던 재태연령이 본 연구에서 유의미한 미숙 아망막병증의 위험요인으로 확인되었고, 30주 미만의 미숙아에서 출생 후 첫 4주간의 산소포화도 변동이 미숙아망막병증의 중증도 에 영향을 미치며, 생후 4주 차의 산소포화도 변동이 클수록 미숙아 망막병증의 중증도가 증가하므로 추후 신생아집중치료실에 입원한 미숙아의 산소치료에서 정밀한 모니터링을 통해 산소포화도 변동 을 최소화하는 것이 미숙아망막병증의 발생과 중증도를 줄이는 데 도움을 줄 것으로 보이며, 산소포화도의 변동이 미숙아의 적정 산소 화 치료 전략에 포함되어야 할 것으로 생각된다.

\section{ARTICLE INFORMATION}

\section{Ethical statement}

This study was approved by the Institutional Review Board of Ajou University Hospital (IRB No. AJIRB-MED-MDB-20-153). Informed consent was waived by the board.

\section{Conflicts of interest}

No potential conflict of interest relevant to this article was reported.

\section{Author contributions}

Conception of design: C.W.J., J.H.L.

Acquisition, analysis or interpretation of data: C.W.J., J.S.K., B.P., J.H.L.

Drafting the work or revising: C.W.J., J.H.L.

Final approval of the manuscript: C.W.J., J.H.L.

\section{ORCID}

Chae Woo Jeon https://orcid.org/0000-0001-6119-2913

Jang Hoon Lee https://orcid.org/0000-0003-4765-9948

\section{Acknowledgments}

None

\section{REFERENCES}

1. Gilbert C, Fielder A, Gordillo L, Quinn G, Semiglia R, Visintin $P$, et al. Characteristics of infants with severe retinopathy of prematurity in countries with low, moderate, and high levels of development: implications for screening programs. Pediatrics 2005;115:e518-25.

2. Maida JM, Mathers K, Alley CL. Pediatric ophthalmology in the developing world. Curr Opin Ophthalmol 2008;19:403-8.

3. Munoz B, West SK. Blindness and visual impairment in the Americas and the Caribbean. Br J Ophthalmol 2002;86:498-504.

4. Wheatley CM, Dickinson JL, Mackey DA, Craig JE, Sale MM. Retinopathy of prematurity: recent advances in our understanding. Arch Dis Child Fetal Neonatal Ed 2002;87:F78-82.

5. Lutty GA, Chan-Ling T, Phelps DL, Adamis AP, Berns KI, Chan CK, et al. Proceedings of the Third International Symposium on Retinopathy of Prematurity: an update on ROP from the lab to the nursery (November 2003, Anaheim, California). Mol Vis 2006;12:532-80.

6. Smith LE. Pathogenesis of retinopathy of prematurity. Semin Neonatol 2003;8:469-73.

7. Arroe M, Peitersen B. Retinopathy of prematurity: review of a seven-year period in a Danish neonatal intensive care unit. Acta Paediatr 1994;83:501-5.

8. Fortes Filho JB, Eckert GU, Procianoy L, Barros CK, Procianoy RS. Incidence and risk factors for retinopathy of prematurity in very low and in extremely low birth weight infants in a unitbased approach in southern Brazil. Eye (Lond) 2009;23:25-30.

9. Sears JE, Pietz J, Sonnie C, Dolcini D, Hoppe G. A change in oxygen supplementation can decrease the incidence of retinopathy of prematurity. Ophthalmology 2009;116:513-8.

10. Tasman W, Patz A, McNamara JA, Kaiser RS, Trese MT, Smith BT. Retinopathy of prematurity: the life of a lifetime disease. Am J Ophthalmol 2006;141:167-74. 
11. Campbell K. Intensive oxygen therapy as a possible cause of retrolental fibroplasia; a clinical approach. Med J Aust 1951;2: 48-50.

12. Patz A, Hoeck LE, De La Cruz E. Studies on the effect of high oxygen administration in retrolental fibroplasia. I. Nursery observations. Am J Ophthalmol 1952;35:1248-53.

13. Ashton N, Ward B, Serpell G. Role of oxygen in the genesis of retrolental fibroplasia: a preliminary report. Br J Ophthalmol 1953;37:513-20.

14. Kinsey VE, Arnold HJ, Kalina RE, Stern L, Stahlman M, Odell G, et al. PaO2 levels and retrolental fibroplasia: a report of the cooperative study. Pediatrics 1977;60:655-68.

15. Smith LE. Through the eyes of a child: understanding retinopathy through ROP the Friedenwald lecture. Invest Ophthalmol Vis Sci 2008;49:5177-82.

16. McLeod DS, Brownstein R, Lutty GA. Vaso-obliteration in the canine model of oxygen-induced retinopathy. Invest Ophthalmol Vis Sci 1996;37:300-11.

17. Donahue ML, Phelps DL, Watkins RH, LoMonaco MB, Horowitz S. Retinal vascular endothelial growth factor (VEGF) mRNA expression is altered in relation to neovascularization in oxygen induced retinopathy. Curr Eye Res 1996;15:175-84.

18. Mantagos IS, Vanderveen DK, Smith LE. Emerging treatments for retinopathy of prematurity. Semin Ophthalmol 2009;24:826.

19. Tin W, Milligan DW, Pennefather P, Hey E. Pulse oximetry, severe retinopathy, and outcome at one year in babies of less than 28 weeks gestation. Arch Dis Child Fetal Neonatal Ed 2001;84:F106-10.

20. Noori S, Patel D, Friedlich P, Siassi B, Seri I, Ramanathan R. Effects of low oxygen saturation limits on the ductus arteriosus in extremely low birth weight infants. J Perinatol 2009;29:553-7.

21. Penn JS, Henry MM, Tolman BL. Exposure to alternating hypoxia and hyperoxia causes severe proliferative retinopathy in the newborn rat. Pediatr Res 1994;36:724-31.

22. Imanishi Y, Hirata K, Nozaki M, Mochizuki N, Hirano S, Fukushima Y, et al. Effect of fluctuation of oxygenation on the development of severe retinopathy of prematurity in extremely preterm infants. J Perinatol 2020;40:515-21.

23. York JR, Landers S, Kirby RS, Arbogast PG, Penn JS. Arterial oxygen fluctuation and retinopathy of prematurity in very-lowbirth-weight infants. J Perinatol 2004;24:82-7.

24. Saito Y, Omoto T, Cho Y, Hatsukawa Y, Fujimura M, Takeuchi T. The progression of retinopathy of prematurity and fluctuation in blood gas tension. Graefes Arch Clin Exp Ophthalmol 1993;231: 151-6.

25. Cunningham S, Fleck BW, Elton RA, McIntosh N. Transcutaneous oxygen levels in retinopathy of prematurity. Lancet 1995;346:1464-5.

26. Das A, Mhanna M, Sears J, Houdek JW, Kumar N, Gunzler D, et al. Effect of fluctuation of oxygenation and time spent in the target range on retinopathy of prematurity in extremely low birth weight infants. J Neonatal Perinatal Med 2018;11:257-63. 